\title{
Management Research of College Finance under Informatization Background
}

\author{
Min Du \\ Zaozhuang University, Zaozhuang, Shandong Province, China
}

Keywords: information environment; college finance; financial management

\begin{abstract}
With the continuous development of informatization technology, great changes have taken place in the work forms of various industries. The low management efficiency in traditional college financial management model cannot meet the needs of financial management in colleges and universities, which requires relevant financial management personnel in colleges and universities to continuously innovate and improve the existing financial management model in the information-based environment, and effectively improve the overall financial management of colleges and universities. This paper carries on the detailed analysis and the research on the college financial management under the informatization environment.
\end{abstract}

\section{Introduction}

In the process of financial management in colleges and universities, only by constantly incorporating the concept of information management, and increasing the informatization construction of financial management in colleges and universities, can we effectively improve the efficiency and management of financial management work in various universities? However, many colleges and universities still have many problems in the process of informatization construction of the financial management system at the present stage, and have severely constrained the effect of financial management in colleges and universities [1]. This also requires the relevant college financial management personnel to continuously improve and innovate the existing college financial management model in an information-based environment, so as to effectively improve the efficiency of current university financial management.

\section{Problems in Financial Management in Colleges and Universities at Present Stage}

\subsection{The contradiction between the increasing importance of financial management and the lack of concept understanding}

In recent years, the development of colleges and universities has changed from large-scale development to connotative development, from the development of injection weight to the development of quality [1]. This requires the management of colleges and universities to change from the original extensive management to fine management. The management of colleges and universities is inseparable from the financial management. The fine management of colleges and universities cannot do without the intellectual support and material security of financial management.

In today's widespread use of management accounting, the financial department should do a good job as the staff and assistants of the school leaders, apply the concept of management accounting to colleges and universities, and provide the basis for the management decision-making of the school leaders. At present, the leaders and decision-makers of many colleges and universities only pay attention to school teaching and research [1]. Career development, while ignore the importance of financial management. They often unilaterally think that the finance department only collects money and pays, and even think that school management decisions are decided by the school leaders, and the financial department only needs to be implemented by the leaders.

2.2 The contradiction between the informatization requirements of financial management and the backward management equipment

At present, the contents and requirements of financial management and accounting have 
undergone tremendous changes, and the tools of financial management have also undergone qualitative changes. However, most college financial management equipment still stays in the accounting computerization stage, and is limited to basic operating tools such as computers and printers [2]. Financial management equipment and environment are far from meeting the requirements of financial management in the new era. In terms of management software, financial management is limited to accounting software, and many colleges and universities do not have specialized financial management software and systems. Backward software cannot meet the management requirements of the "Internet Plus" era.

\subsection{The contradiction between the meticulous requirements of financial management and the backward financial team}

In recent years, with the continuous deepening of various fiscal reforms and the establishment of a public finance system, the financial departments have put forward higher requirements for the use of fiscal funds, including the requirements of the Budget Law for budget preparation, implementation, and evaluation systems. "Procurement Law" requirements for procurement projects and procedures, "government revenue and expenditure classification subjects" requirements for expenditure are on economic subjects, the treasury centralized payment system requirements for fund payments, and the requirements of the official card system for fund settlement [2]. All of these requirements have caused great changes in the original financial operation system in colleges and universities, requiring that the financial management of universities must be standardized and scientific.

The knowledge level and professional quality of financial management personnel is the key to determining the level of financial management. At present, many colleges and universities only pay attention to the introduction and cultivation of teaching and research talents, and neglect the construction of accounting teams. The accounting personnel of colleges and universities have an aging phenomenon, and the number of financial personnel is also seriously insufficient [2]. At the same time, the existing financial personnel's business knowledge and quality needs to be improved, and the knowledge in the new information age is seriously lacking.

\section{The Actual Situation and Existing Problems of financial Information Management in Colleges and Universities}

Under the unremitting efforts of the leadership and the relevant staff in the national education sector, China's current digitization of financial management information in colleges and universities has achieved some remarkable results. Digital universities must also closely follow the ongoing reform of the national economic development education. The pace of progress, continuous bold scientific innovation, fundamentally changing the financial management methods, at this stage, China's digital financial management has highlighted many serious problems, the need for professional staff to solve in a timely manner, to avoid the entire [3]. The serious harm caused by the management system greatly hinders the rapid development of informationization.

\subsection{Problems in understanding informationization}

For colleges and universities with digital development, how to make full use of the positive role of financial management on campus has become one of the most important issues in the current university information construction. In the actual development of informatization, there is a case where there is a mistake in the definition of the informationization. There are mainly two cases. The first one is: Some people think that vigorously building the information management system and tradition of university financial affairs the systematic construction methods are basically the same, and there is no need to waste too much manpower, material resources, and financial resources to build this management system. Second, people's cognitive perspectives are one-sided, and they have not been able to have a comprehensive understanding of information construction activities in colleges and universities [3]. They believe that as long as there is management software and related website management, regular updating of the financial management process will result in the completion of colleges and universities. There are also a small number of people who have forcibly separated 
financial information management from digitized universities and separated them, and managed it as a separate part. They autonomously believe that digital construction of universities and financial information management can be independently managed. The finance department does not need to rely on the whole university [3]. The above two kinds of erroneous cognitions have relatively one-sided understanding of the management of financial informationization construction in digital colleges and universities, and all of them just over-emphasize the short-term benefits and do not really consider the continued development of campus follow-up construction.

\subsection{Lack of emphasis on financial information management}

Many colleges and universities in the process of financial management often do not pay enough attention to information management, and cannot be a good construction of a financial management objectives and management system, which makes the financial management of the entire university, presents a chaotic management situation [4]. And many colleges and universities in the process of financial management information construction did not build a special financial database, which also seriously affected the financial management efficiency of the entire university.

\subsection{Lack of rationality in the budget management}

In the implementation process of financial information management in some colleges and universities, there are often two kinds of budgets adopting a kind of budget mode. The overall financial management also presents the problem of lack of scientificization [4]. This has led to many universities in the financial management process can not be a good scientific evaluation of financial efficiency, and makes the entire financial management work is difficult to carry out in an orderly manner.

\subsection{Lack of security in the financial management information construction process}

Some colleges and universities did not build a good network protection mechanism during the use of financial management software. This made it possible that problems such as disclosure of financial information may occur in the management process, and would bring huge financial management to the university [3]. This also requires the relevant financial management personnel to fully enhance their own safety awareness in the course of their daily work and achieve the best financial information management status.

\section{The Innovation Strategy of Financial Management in Colleges and Universities in Informatization Environment}

\subsection{Build a financial management information system}

With the advent of the age of information, in order to be able to improve the level of financial management in colleges and universities, it is necessary for relevant universities to focus on the construction of a financial information management system during the process of financial information management. In the process of the construction and improvement of the system, colleges and universities should fully consider their own financial actual conditions, financial management objectives and other factors to achieve a scientific and safe financial management. Under the premise of establishing a financial management information system, in order to fully guarantee the financial management security of the university, it is necessary to fully emphasize user information management technology and other information security technologies in the process of the system's control [5]. Moreover, in the course of the construction of the financial management information system, it should also fully emphasize the further improvement of the scientific rules and regulations and the management system, so that it can help the relevant financial management personnel to be able to do so in the actual work process. Reference, and achieve a scientific financial management status. In addition, during the process, the supervision of the operating status of the entire information system should also be strengthened, and some issues that arise in the system should be handled in a timely manner. 


\subsection{Improve the interactive mechanism in the financial management process}

On the basis of informatization technology, in order to realize the innovation of financial management in colleges and universities, it is necessary for universities and colleges to carry out relevant practice management work, and to be able to successfully manage the financial information and financial management needs. The financial management work carried out in-depth analysis, and at the same time based on the analysis results, to construct some of the recent financial management goals and long-term financial management objectives [6]. Moreover, in the process of financial management innovation in colleges and universities, the relevant financial management departments should also fully improve their interaction mechanisms in daily management work, and they can use the campus network, microblogging and other platforms to build financial management departments in colleges and universities. With the establishment of a good interactive system, the financial information can be effectively shared with colleges and universities in a timely manner, and to obtain an optimal state of financial information management, and can fully meet the needs of the sustainable development of universities [5]. In the process of financial management model innovation, universities should also fully utilize information technology to build an online financial management system to effectively improve the financial management efficiency of the university.

\subsection{Further improve the financial management information system}

On the basis of informatization technology, in order to create a good financial management model, it is necessary for colleges and universities to fully improve their own financial management system in the daily management process, which requires universities and colleges to first improve the management of financial personnel. For example, in the practice of financial information management, colleges and universities should arrange financial personnel to participate in a specialized training program and need to fully cultivate the awareness of information management of financial management personnel during the training process [6]. Guide these financial management personnel in the daily work process, can take the initiative to use some information technology to carry out financial management, so that it can effectively improve the overall quality of financial management personnel and management quality of the entire university. In addition, colleges and universities should also pay attention to the data of financial information and improve management principles in the process of innovation in financial information, and use this to effectively adjust the probability of loss of the entire financial data, so as to improve the accuracy of financial management in universities.

\subsection{Establish a school data center, and implement data sharing among various departments within the school}

With the continuous emergence and application of new technologies such as mobile internet, internet of things, big data and cloud computing, financial management in colleges and universities will face new opportunities and challenges. Colleges and universities should continue to explore new financial management models and establish school data centers. Financial management information will be centrally managed through data centers, and college financial services and data centers will be interconnected [7]. The college administrators input financial management information into the information processing system through the terminal. The information processing system performs data processing through the computer, supplements the Internet "big data" for financial analysis, generates financial analysis data, and feeds back relevant query systems in time, so as to manage the universities.

\subsection{Upgrade the accounting system and establish an integrated financial management information system}

With the development of information technology and the widespread use of the Internet, colleges and universities need to upgrade the original accounting system, establish a financial management information system, and associate the financial management information system as a subsystem of the university management system with other management subsystems. Financial management 
information system achieves the purpose of improving the use of funds in colleges and universities through budget preparation, fund raising and use [6]. According to the financial activities of colleges and universities and the characteristics of their financial relations, data sharing is carried out with school student status management system, educational administration management system, library management system, scientific research project management and personnel management system, so that the school assets and financial system can be merged to truly achieve financial results.

\subsection{The use of "Internet +" to promote the development of college management accounting}

In October 2014, the Ministry of Finance issued the "Guiding Opinions on Promoting the Construction of the Management Accounting System in an All-round Way," striving to achieve a significant improvement in the level of management accounting information through 5-10 years of time, and encourage the unit to manage accounting information requirements. Incorporate information planning [7]. According to the specific characteristics of colleges and universities, in order to promote the development of university management accounting, colleges and universities should strengthen the awareness of the Internet and use the "Internet +" thinking [7]. First, we must strengthen the "Internet +" thinking and promote innovation in management accounting; second, we must use Internet technology to achieve a full-process management accounting service system; and third, we must promote the internal and external interconnection of the management accounting system, and consolidate the industry-university-research alliance, foster and develop talents in universities.

\section{Summary}

Many colleges and universities in China still have many problems in the process of financial management information construction, and have severely restricted the financial management quality and management efficiency of the university. This also requires that relevant universities must integrate information technology into financial management, and continuously innovate and improve the existing financial management model. Only in this way can we effectively strengthen the quality and efficiency of financial management throughout the university and promote the sustainable development of the university.

\section{References}

[1] X.H. Yin, Application of computer network technology in enterprise financial management, Chinese Business, 2010, vol.9, pp.7-9.

[2] X.Y. Jing, Information management of financial management, Science and Technology Innovation Guide, 2011, vol.2, pp.54-56.

[3] Y.J. Cao, Research on Innovation of Accounting Management in Colleges and Universities under Information Environment, Educational Modernization.2016, vol.2, pp.43-45.

[4] Y.X. Zhang, School nets and joint innovation of financial settlement mode in colleges and universities, Times Finance, 2015, vol.11, pp.3-6.

[5] Y.M. Chen, Research on innovative mode of financial management in colleges and universities based on informatization, Business accounting, 2012, vol.3, pp.44-46.

[6] M.T. Nie, X.Y. Zhang, Research on Innovative Application of Internet and University Financial Management Informatization, Commercial Economy, 2016, vol.6, pp.63-65.

[7] Q.X. Du, “Internet +" Financial Accounting Reform in Colleges and Universities, Economist, 2016, vol.6, pp. 32-34. 